\title{
Vezljivostni slovar slovenskih glagolov Andreje Žele
}

\author{
Branislava Vičar
}

Andreja Žele, Vezljivostni slovar slovenskih glagolov, Ljubljana: Založba ZRC, ZRC SAZU, 2008 (Slovarji), 529 str. + CD-ROM

Enojezični razlagalni slovar Vezljivostni slovar slovenskih glagolov Andreje Žele je normativno leksikografsko delo moderne slovenske vezljivosti. Avtorica $\mathrm{z}$ izbranim gradivnim pomenskoskladenjskim izhodiščem in natančno izdelano tipologijo glagolske vezljivosti zajame tipično vezljivost slovenskih glagolov. Različne ravni vsebinskopredstavitvene zasnove slovarskega sestavka izpolnjujejo zahteve različnih uporabniških skupin, tako jezikovno specializiranih bralcev kot širšega kroga uporabnikov.

Ključne besede: slovenščina, slovarji, glagolska vezljivost

\section{Valency Dictionary of Slovenian Verbs by Andreja Žele}

The monolingual explanatory dictionary Valency Dictionary of Slovenian Verbs by Andreja Žele is a normative lexicographic work on modern Slovenian valency. The author deals with the typical valency of Slovenian verbs by creating a detailed typology of verbal valency while taking into account its semantic and syntactic basis in language use. The dictionary articles contain various levels of presentation and explanation and thus meet the needs of various user groups, including both linguists and a more general audience.

Key words: Slovenian, dictionaries, verbal valency

0 Normativno leksikografsko delo moderne slovenske vezljivosti je že desetletja deziderat slovenske leksikografije. Premostitveni slovaropisni projekt s področja sodobne slovenske vezljivosti, poleti 2008 izšli enojezični razlagalni slovar Vezljivostni slovar slovenskih glagolov (VSG) avtorice Andreje Žele zajema slovensko glagolsko vezljivost kot temeljno in zato najobsežnejšo. Namenjen je trem uporabniškim skupinam: a) zahtevnejšim naslovnikom, ki želijo podrobneje spoznati vezljivostne zmožnosti slovenskih glagolov, b) učiteljem, učencem in študentom, zlasti tistim, ki se učijo slovenščine kot tujega jezika, c) jezikoslovno nespecializiranim bralcem, ki bodo v slovarju iskali zgolj informacijo, s katerim sklonom je najustrezneje vezati uporabljeni glagolski pomen. Kot predpostavlja avtorica slovarja, bo prva skupina potencialnih uporabnikov prebrala celotni teoretični uvod in (vsaj) pregledala vezljivostne obrazce, slednji dve skupini pa se bosta omejili samo na informativne legende, ki omogočajo lažjo orientacijo po slovarju (VSG: 7). 
- 1 Vezljivostni prispevek avtoričinih doslej izdanih monografij (predstavitev vezljivostne tipologije glagolov in izglagolskih tvorjenk v slovenskem knjižnem jeziku (Žele 2001) ter vzorčna predstavitev pomensko- in strukturnoskladenjske vezljivosti po vseh nosilnih glagolskih pomenskih skupinah (Žele 2003)) in vidnejših razprav, ki jim lahko sledimo od devetdesetih let dalje (večravninske - pomenska, skladenjskofunkcijska, izrazna ravnina - teoretične obravnave slovenske (zlasti glagolske) vezljivosti, kronološko-problemske predstavitve domače in tuje vezljivostne literature), izkazuje avtoričino specializiranost na področju sinhrone slovenske vezljivosti in širino pregleda nad najpomembnejšo vezljivostno strokovno literaturo. Dobro izhodišče dalje zagotavlja leksikološki (mdr. razpravljanja o nekaterih vsebinskih, terminoloških in tehničnih rešitvah v SSKJ, prikazovanje različnih vidikov obdelave slovarskega članka, presojanje meril za izbiranje slovarskega ponazarjalnega gradiva iz korpusov, razpravljanja o gradivni osnovi za novi slovar slovenskega jezika) in leksikografski (npr. soavtorstvo Besedišča slovenskega jezika z oblikoslovnimi podatki (Šircelj-Žnidaršič 1998) s 178.457 iztočnicami, ki po slovarskih načelih niso bile sprejete v SSKJ) prispevek avtorice, ki potrjuje tudi njeno slovaropisno kompetenco.

2 VSG vezljivostno analizira 2591 glagolov kot slovarskih enot oz. gesel, od tega 2061 glavnih izhodiščnih gesel in 530 kazalčnih gesel (pri vidsko nasprotnih glagolih z delno pomenskoskladenjsko prekrivnostjo). Obseg je bil določen po merilu zajetja pomenskoskladenjsko temeljnejših glagolov iz vseh nosilnih vezljivostnih skupin glagolov: slovar vključuje glagole iz petih osnovnih glagolskih pomenskih skupin (stanjske glagole (telesno in duševno stanje) z glagoli nastajanja, glagole ravnanja/upravljanja/ustvarjanja, glagole govorjenja/razumevanja/mišljenja, glagole spreminjanja in glagole premikanja; vse s faznimi in naklonskimi različicami).

3 Namen VSG je zajeti vso tipično vezljivost slovenskih glagolov. Avtorica ga izpolnjuje (1) z izbranim gradivnim pomenskoskladenjskim izhodiščem in (2) z natančno izdelano tipologijo glagolske vezljivosti.

3.1 Leksikalno izhodišče in osnovno vodilo pri hierarhičnem razvrščanju pomenov je Slovar slovenskega knjižnega jezika (SSKJ) kot temeljni enojezični razlagalni slovar slovenščine. Kljub temu da SSKJ glede na osnovni pomenskorazlagalni slovarski koncept z vidika leksikografske zasnove zgradbe slovarskega sestavka ne predstavlja zahtevam modernega enojezičnega vezljivostnega slovarja primerne zasnove, ${ }^{1}$ je gradivna osnova $\mathrm{z}$ verižno predstavitvijo vezljivosti v smislu pomen-

Na pomanjkljivost pomenskih razlag v SSKJ z vidika vezljivosti je Andreja Žele že večkrat opozorila, mdr. v uvodu k VSG (9): »[P]omenske razlage praviloma ne ločujejo med zgolj pomensko sestavinskostjo obravnavanega leksema in že vključevanjem tudi udeležencev obravnavanega leksema oz. izražanjem pomensko- in strukturnoskladenjske vezljivostne omejitve obravnavanih leksemov.« Prim. tudi Orešnik 1992: 164. 
skohierarhične vezljivostne mreže glagolov (primarnih $>$ temeljnih $>$ specializiranih) v VSG dosegla svojemu namenu primerno raven. $Z$ vidika vezljivostne aktualizacije je pomembno aktualizacijsko preverjanje in kritično usklajevanje pomenskoin strukturnoskladenjske rabe glagolov z današnjo aktualno/živo rabo pri redakciji pretežno znanih glagolov oz. glagolskih gesel, to pa je tudi ena najmočnejših točk slovarskega projekta. Po aktualnostnem merilu so bili v slovar sprejeti tudi nekateri novi pogosto rabljeni glagoli, ki jih SSKJ ne vključuje, npr. dopisnikovati, dopingirati, filmizirati. Upoštevanje jezikovno živega in aktualnega besedja kaže na odgovornost avtorice modernega enojezičnega slovarja za kodificiranje dejanskega obstoječega jezikovnega stanja.

3.2 Vezljivostno tipologijo glagolov (in izglagolskih tvorjenk) v slovenskem knjižnem jeziku je Andreja Žele izdelala že leta 2001 v svoji prvi monografiji Vezljivost v slovenskem knjižnem jeziku (2001) in s tem oblikovala zasnovo vezljivostnega slovarja slovenščine. Z vzorčnim prikazom slovarskih sestavkov iz osnovnih pomenskoskladenjskih skupin glagolov v skladenjsko normativnem vezljivostnem priročniku Glagolska vezljivost: iz teorije v slovar (2003) je vezljivostno teorijo prenesla $\mathrm{v}$ slovarsko prakso in $\mathrm{s}$ tem napovedala VSG. ${ }^{2}$

$4 \quad$ Najpomembnejše za uporabnika VSG je vprašanje zgradbe slovarskega sestavka, tj. vprašanje, s katere vrste podatki in na kateri način je predstavljena vezljivost posameznega glagola. Konkretna izvedba slovarskih sestavkov je sorazmerna z zahtevno zastavljeno zasnovo VSG in visoko zastavljenimi merili obdelave in predstavitve gradiva.

4.1 Andreja Žele vključuje v slovarski sestavek VSG tele podatke: 1. glagolsko geslo; 2. pomensko razlago; 3 . podatke o vezljivosti, tj. t. i. vezljivostni obrazec oz. pomenskoskladenjsko vezljivostno formulo; 4. ponazarjalno gradivo; 5. pogostejše pretvorbene stavčne obrazce; 6 . enakovezljivostnice; 7. pri terminoloških označevalnikih podatke o terminološki vezljivosti. Obdelava slovarskih sestavkov je izčrpna in sporočilno natančna.

2 Kot zgled za oblikovanje vezljivostnih glagolskih pomenskih skupin je uporabila vezljivostno delitev čeških glagolov v delu Větné vzorce v češtině F. Daneša in sodelavcev (Daneš idr. 1987). Pri prikazu vezljivosti oz. pomenskohierarhične vezljivostne mreže glagolov Andreja Žele predstavlja pomenskohierarhična razmerja primitivni glagol : temeljni glagol : specializirani glagol. Vezljivostna predstavitev gre v smeri specializirani glagol $\rightarrow$ temeljni glagol $\rightarrow$ primitivni glagol in je torej usmerjena k bazičnim glagolom biti, imeti, delati, ki vezljivostno pokrivajo vse glagole. Izhodišče in obenem stičišče celotne vezljivostne mreže so temeljni glagoli. Ti so osnovno delitveno merilo za glagolske vezljivostne skupine ter hkrati pomenskoskladenjska osnova in izhodišče za pomensko specializirane glagole. 
4.1.1 Glagolska gesla so urejena abecedno, zato so na koncu posameznih glagolskih pomenov ali na koncu geselskih sestavkov kot vodilke s krajšavo prim. "primerjaj' za podpičjem navedene enakovezljivostnice. Zaradi ohranjanja abecedne razvrstitve iztočnic je vsako geslo opremljeno z oznako vezljivostne skupine, ki ji glagol pripada, npr. potovati $\mathrm{P}_{\mathrm{Pr} / \mathrm{C} / \mathrm{Dg}}(=$ glagol (procesnega/ciljnega/dogodkovnega) premikanja), za ustrezno uporabo pa so dodani slovnično-pomenski podatki (vidski podatek) in stilno-zvrstni označevalniki.

Kot samostojne iztočnice so nastavljeni prostomorfemski glagolski leksemi z leksikaliziranimi neudeleženskimi zaimenskimi in predložnimi morfemi kot pomensko-izraznimi sestavinami leksema, npr. premisliti se/si 'spremeniti odločitev', mahati jo 'hitro se premikati'; biti ob 'izgubiti', hoditi $\boldsymbol{z a}$ 'dvoriti', vstati proti 'upreti se', in najtipičnejši glagolski frazemi.

$\mathrm{V}$ smislu posebnih gesel so izpostavljene vezavnostne posebnosti pri glagolih $\mathrm{z}$ dokazano težnjo po širitvi tožilniške vezave z upoštevanjem možnosti brez se, npr. abstinirati, abstinirati se; specializirati, specializirati se.

T. i. dvojno geslo nastopa pri vidskoparnih glagolih tipa postaviti - postavljati; slovarski sestavek je popolno izpisan pod tistim glagolom vidskega para, ki ima večjo in aktualnejšo rabo (npr. postaviti nasproti postavljati), kazalčno geslo je uvedeno z napovedno okrajšavo gl. 'glej'. Vidskonasprotni glagoli z delno pomenskoskladenjsko prekrivnostjo tipa kupiti - kupovati so slovarsko prikazani z obojesmernimi kazalkami oz. kazalčnimi gesli, tako da so isti/skupni pomeni obdelani pod izhodiščnim/osnovnim geslom s popolnim slovarskim prikazom, dodani pomeni pa v komplementarnem kazalčnem geslu. Kot pri glagolskih geslih z vidskimi pari je tudi pri geslih $\mathrm{z}$ vidskimi nasprotji upoštevano pravilo rabe.

Enakozvočna gesla so dodatno označena z rimskimi številkami, npr. stati I, stati II.

4.1.2 Temeljno urejevalno načelo slovarskega pomena je sintagmatsko - podredno razmerje pomenskih sestavin je določeno $\mathrm{z}$ vodilno uvrščevalno pomensko sestavino (UPS) in določujočimi razločevalnimi pomenskimi sestavinami (RPS). Pri večpomenskih leksemih kot slovarskih enotah so posamezni pomeni predstavljeni ločeno. Zaporedje pomenov je določeno po merilu aktualnosti in $\mathrm{z}$ njo povezane pogostnosti. S pomenskohierarhičnim pomenjem je označena popolna pomenskoskladenjska vezljivost. Številka ob glagolu oz. ob vsakem glagolskem pomenu, npr. potovati $_{1(2)}$ (nasproti potovati ${ }_{2}$ ), pove, ali je določeni glagolov skladenjski pomen nič-/ne- ${ }_{0}$, eno- ${ }_{1}$, dvo- $_{2}$, tro- ${ }_{3}$ ali večvezljiv. Prva številka ob glagolu pove število obveznovezljivih določil; če sledi še številka v oklepaju, pomeni, da ima glagol tudi določeno število neobveznovezljivih določil. Pri načinu prikaza so najpomembnejši vezljivostni podatki označeni $z$ rdečo barvo. $V$ pomenskih razlagah je upoštevana oklepajna hierarhija: neobvezna določila so označena z okroglimi oklepaji, nevezljiva dopolnila so $\mathrm{v}$ poševnih oklepajih.

4.1.3 Pomenskoskladenjske vezljivostne formule označujejo osnovno pomenskoskladenjsko vezljivost posameznih glagolskih pomenskih skupin. Oblikujejo jih kombinacije pomenskih oznak (za vrste dejanj in pomenske vloge udeležencev), 
zgradbenih oznak (za oblikoslovno-skladenjske oz. besednovrstne lastnosti določil) in oznak za stavčna razmerja. Namenjene so predvsem jezikoslovcem; zapisane so v sivi barvi in s tem optično postavljene v ozadje. Pomenskoskladenjska formula upošteva udeležence (s predmetnopomenskimi in slovničnokategorialnimi lastnostmi kot živo ${ }^{+/-}$, človeško ${ }^{+/}$, abstraktno ${ }^{+/}$, konkretno ${ }^{+-}$) in vse pomenskoobvezne udeleženske vloge (vršilec, prejemnik, prizadeto, vzrok, cilj, sredstvo, rezultat ipd.) v oglatem oklepaju, ki so strukturnoskladenjsko obvezne ali neobvezne (neobvezne so označene z okroglim oklepajem).

Zgled za glagol potovati kot primer glagola premikanja s pomenskopodstavnim elementarnim glagolom premikati se: $\operatorname{Sam}_{1} \mid \mathrm{xNp} \mathrm{ż}^{+/-}$abstr. $^{-/+} \mid+$Glag $\left|\mathrm{M}_{\text {so }}\right|$ $\left(+\mathrm{p} \cap \mathrm{Sam}_{2-6} / \operatorname{Prisl}_{\mathrm{k}}\left|\mathrm{yM} / \breve{\mathrm{C}} / \operatorname{Pot}_{\mathrm{p}} \breve{z}^{-/+}\right|\right) /+{ }_{\mathrm{kot}} \mathrm{Sam}_{1} / \mathrm{p} \cap \mathrm{Sam}_{2-6} / \mathrm{Prisl}_{\mathrm{n} / \mathrm{kol} / \mathrm{vz}} \mid \mathrm{wN} / \mathrm{Kol} /$ $\mathrm{Vz}_{\mathrm{p}} \mid /$ (= pomen 'premikati se s korakanjem' ima: (1) imenovalniško določilo $\mathrm{v}$ okviru leve vezljivosti (besednovrstno je samostalnik); udeleženec: 1. delovalnik (x); skladenjski pomen oz. udeleženska vloga: nosilec procesa; slovničnokategorialne lastnosti udeleženca: živo ${ }^{+/}$, abstraktno $^{-/+}$; (2) neobvezno predložnosklonsko določilo (besednovrstno je to samostalniška beseda v rod./daj./tož./mest./orod. predložni morfem se pri tem slovnično ujema s samostalniško končnico) oziroma prislovno določilo (besednovrstno je to prislov kraja); udeleženec: 2. delovalnik (y); udeleženska vloga: mesto/čas/potek procesa; slovničnokategorialne lastnosti udeleženca: živo ${ }^{-1+}$; in (3) pomenskoskladenjsko obvezno nevezljivo dopolnilo, in sicer imenovalniško ali preložnosklonsko (besednovrstno je samostalniška beseda - predložni morfem se pri tem slovnično ujema s samostalniško končnico) oziroma prislovno (besednovrstno je prislovni dopolnilnik prislov načina/količine vzroka); udeleženec: lastnost (w); udeleženska vloga: način/količina/vzrok procesa).

4.1.4 Ponazarjalno gradivo je zbrano in urejeno sorazmerno z natančnostjo pomenskih in zgradbenih slovarskih oznak. Jezikovno živi in aktualni ponazarjalni zledi omogočajo vezavno aktualizacijo pretežno znanih glagolov in vezavni prikaz nekaterih novih pogosto rabljenih glagolov. V smislu sporočilne hierarhije so zgledi v navadnem tisku. Oklepajna hierarhija je usklajena s hierarhijo v pomenskih razlagah: neobveznovezljiva določila so navajana v okroglih oklepajih, nevezljiva (samo skladenjskoobvezna) dopolnila so v poševnih oklepajih, npr. potovati ${ }_{1(2)}$ : /Redno/ potujejo (na poletne počitnice).

4.2 Različne ravni vsebinskopredstavitvene zasnove slovarskega sestavka izpolnjujejo zahteve različnih uporabniških skupin: širšemu krogu uporabnikov so namenjeni osnovni in hkrati najpomembnejši vezljivostni podatki; ti so pri načinu prikaza vezljivosti označeni z rdečo barvo. Zlasti jezikoslovcem pa so namenjene pomenskoskladenjske formule; te so označene s sivo barvo črk in s tem umaknjene v ozadje. Različne tipografske rešitve v smislu sporočilne hierarhije izpolnjujejo leksikografsko načelo, da se informacije različnih vrst tudi optično oz. oblikovno razlikujejo.

Poudariti velja, da je slovar hkrati izšel v knjižni in digitalni obliki; elektronska izdaja omogoča iskanja na različnih zahtevnostnih stopnjah. 
- 5 Vezljivostni slovar slovenskih glagolov Andreje Žele je temeljni slovar in [. N slovenske leksikografije in bo koristen pripomoček različnim skupinam uporabni- $\quad$ kov - seveda na različnih ravneh uporabe. Največje odlike slovarja so povezanost pomenske vezljivosti s strukturnoskladenjsko vezljivostjo pri opredelitvah glagolskih gesel, metodološka preciznost, upoštevanje žive in aktualne jezikovne rabe ter večnivojska vsebinskopredstavitvena zasnova.

\section{Literatura}

Daneš idr. 1987 = František Daneš idr., Větné vzorce v češtině, Praha: Academia, 1987.

Orešnik 1992 = Janez Orešnik, Udeleženske vloge v slovenščini, Ljubljana: SAZU, 1992 (Dela razreda za filološke in literarne vede 37).

SSKJ = Slovar slovenskega knjižnega jezika 1-5, Ljubljana: SAZU oz. ZRC SAZU (izd.) - DZS (zal.), 1970-1991.

Šircelj-Žnidaršič 1998 = Ivanka Šircelj-Žnidaršič (ur.), Besedišče slovenskega jezika z oblikoslovnimi podatki, Ljubljana: Založba ZRC, ZRC SAZU (Slovarji).

Vidovič Muha 1986 = Ada Vidovič Muha, Besedni pomen in njegova stilistika, Seminar slovenskega jezika, literature in kulture: zbornik predavanj 22 (1986), 79-91.

Žele 2001 = Andreja Žele, Vezljivost v slovenskem jeziku (s poudarkom na glagolu), Ljubljana: Založba ZRC, ZRC SAZU, 2001 (Linguistica et philologica 4).

Žele 2003 = Andreja Žele, Glagolska vezljivost: iz teorije v slovar, Ljubljana: Založba ZRC, ZRC SAZU, 2003 (Linguistica et philologica 8). 